\title{
Pregnancy Outcome in a Thyroid Cancer Survivor
}

\author{
Lubna Riaz Dar ${ }^{1}$, Shaherzad Sohail ${ }^{2}$, Afreen Farid ${ }^{3}$ \\ Gynecology and Obstetrics Department Shalamar Medical and Dental College, Lahore ${ }^{1,2,3}$
}

\begin{abstract}
Background: Pregnancy after papillary thyroid carcinoma (PTC) is rarely seen. Monitoring of such pregnancy is very challenging as normal thyroxin levels are essential for satisfactory perinatal outcome. Besides the effect of carcinoma, its surgery, radioactive iodine therapy and psychosocial factors need to be considered.

Case presentation: A 28 years old lady presented to Obstetrics / Gynecology outpatient department at 30 weeks for antenatal check-up of her first pregnancy in December 2018. Patient had papillary thyroid cancer in 2008 , it was staged $\mathrm{T}_{2} \mathrm{~N}_{1} \mathrm{M}_{1}$. She also had metastasis in cervical lymph nodes and lungs. It was treated by total thyroidectomy and para-thyroidectomy with bilateral neck dissection followed by two doses of radioactive iodine till 2011. She was followed up by her oncologist and they allowed her to conceive and continue pregnancy. Our patient had an uneventful pregnancy. She was delivered by caesarean section and the baby had to stay in neonatal unit for one day. Multidisciplinary approach, special attention in antenatal and perinatal period can result in successful outcome of pregnancy in post treatment patients of papillary thyroid carcinoma.

Conclusion: Reports of pregnancies after papillary thyroid carcinoma are rare and its management is challenging. Multidisciplinary approach and attention to their special needs can lead to satisfactory pregnancy outcome.
\end{abstract}

Key words: Papillary thyroid carcinoma, PTC, Pregnancy, Hypothyroidism

\section{INTRODUCTION}

These days chances of conception are increased even after the treatment of cancers. Successful pregnancies are observed in case of cancers. Papillary thyroid carcinoma (PTC) makes 70\% of all the thyroid carcinomas with higher incidence seen in women and after the age of $40 .{ }^{1,2}$ It is rarely seen in young girls and in this situation desire to conceive after treatment is natural. Pregnancy after surgery and radioactive iodine therapy of PTC becomes more

\section{Corresponding Author:}

Prof. Dr. Lubna Riaz Dar

Gynecology and Obstetrics Department

Shalamar Medical and Dental College, Lahore

Email address: Lubna.riaz.dar@gmail.com

Received 22.05.2019, Revised 10.06.2019, Accepted 20.06.2019 challenging as hypothyroidism can cause miscarriage, fetal growth restriction and affects fetal brain development. ${ }^{3}$. If parathyroid gland is removed with thyroidectomy then plasma calcium control is to be monitored which becomes more crucial during pregnancy and especially during delivery. Fear of carcinoma and its treatment effect can cause psychosocial affects which has to be considered during pregnancy. In this case report we present the problems faced in the management of our patient who became pregnant after surgery and radioactive iodine therapy for papillary thyroid carcinoma. These days chances of conception are increased even after the treatment of cancers. Successful pregnancies are observed in case of cancers. Papillary thyroid carcinoma (PTC) 
makes $70 \%$ of all the thyroid carcinomas with higher incidence seen in women and after the age of $40 .{ }^{1,2}$ It is rarely seen in young girls and in this situation desire to conceive after treatment is natural. Pregnancy after surgery and radioactive iodine therapy of PTC becomes more challenging as hypothyroidism can cause miscarriage, fetal growth restriction and affects fetal brain development. ${ }^{3}$ If parathyroid gland is removed with thyroidectomy then plasma calcium control is to be monitored which becomes more crucial during pregnancy and especially during delivery. Fear of carcinoma and its treatment effect can cause psychosocial affects which has to be considered during pregnancy. In this case report we present the problems faced in the management of our patient who became pregnant after surgery and radioactive iodine therapy for papillary thyroid carcinoma.

\section{CASE PRESENTATION}

A 28 years old lady presented to gynecology outpatient department at 30 weeks for antenatal check-up of her first pregnancy in December 2018. Patient had papillary thyroid cancer in 2008 , it was staged $\mathrm{T}_{2} \mathrm{~N}_{1} \mathrm{M}_{1}$. She also had metastasis in cervical lymph nodes and lungs. It was treated by total thyroidectomy and parathyroidectomy with bilateral neck dissection followed by two doses of radioactive iodine till 2011. She was followed up by her oncologist and they allowed her to conceive and continue pregnancy. When she came to us, she was hypothyroid and hypo-parathyroid. She was taking thyroxin, calcium and vitamin D supplements. She presented to us during her third trimester. More than half of pregnancy had passed. She was investigated for levels of thyroxin, calcium and vitamin D. All came out within normal range. When she presented to us for first booking visit, we advised her

Table 1: Laboratory Findings of the Patient with Thyroid Carcinoma

\begin{tabular}{|c|c|c|}
\hline Investigations & Patient Value & Normal Ranges \\
\hline $\begin{array}{l}\text { Complete Blood Count (CBC) } \\
\text { Haemoglobin (Hb) } \\
\text { Total Leukocyte Count (TLC) } \\
\text { Platelets count }\end{array}$ & $\begin{array}{l}13 \mathrm{~g} / \mathrm{dl} \\
7500 / \mu \mathrm{L} \\
129,000 / \mu \mathrm{L}\end{array}$ & $\begin{array}{l}12.5-15.5 \mathrm{~g} / \mathrm{dl} \text { (Females) } \\
4000-11000 / \mu \mathrm{L} \\
150,000-450,000 / \mu \mathrm{L}\end{array}$ \\
\hline $\begin{array}{l}\text { Liver function tests (LFT's) } \\
\text { Alanine transaminase (ALT) } \\
\text { Aspirate aminotransferase (AST) } \\
\text { Alkaline phosphates (ALP) }\end{array}$ & $\begin{array}{l}140 \mathrm{U} / \mathrm{L} \\
80 \mathrm{U} / \mathrm{L} \\
233 \mathrm{U} / \mathrm{L}\end{array}$ & $\begin{array}{l}5-40 \mathrm{U} / \mathrm{L} \\
5-40 \mathrm{U} / \mathrm{L} \\
40-135 \mathrm{U} / \mathrm{L}\end{array}$ \\
\hline $\begin{array}{l}\text { HBs Ag } \\
\text { Anti HCV }\end{array}$ & $\begin{array}{l}\text { Non-Reactive } \\
\text { Non-Reactive }\end{array}$ & $\begin{array}{l}\text { Non-Reactive: }<0.9 \\
\text { Border line: } 0.9 \text { to } 1.0 \\
\text { Reactive: }>1.0\end{array}$ \\
\hline $\begin{array}{l}\text { Renal function tests (RFT's) } \\
\text { Urea } \\
\text { Creatinine }\end{array}$ & $\begin{array}{l}20 \mathrm{mg} / \mathrm{dl} \\
0.6 \mathrm{mg} / \mathrm{dl}\end{array}$ & $\begin{array}{l}10-50 \mathrm{mg} / \mathrm{dl} \\
0.50-1.30 \mathrm{mg} / \mathrm{dl}\end{array}$ \\
\hline $\begin{array}{l}\text { Thyroid Function Test (TFT) } \\
\text { Thyroid stimulating hormone (TSH) } \\
\text { FreeT4 }\end{array}$ & $\begin{array}{l}0.118 \mu \mathrm{lU} / \mathrm{ml} \\
1.22 \mathrm{ng} / \mathrm{dl}\end{array}$ & $\begin{array}{l}0.30-4.20 \mu \mathrm{lU} / \mathrm{ml} \\
0.90-1.70 \mathrm{ng} / \mathrm{dl}\end{array}$ \\
\hline $\begin{array}{l}\text { Oral Glucose tolerance test } \\
\text { (OGTT) } \\
\text { Fasting Blood Glucose } \\
\text { Blood Glucose after } 1 \mathrm{hr} \\
\text { Blood Glucose after } 2 \mathrm{hr}\end{array}$ & $\begin{array}{l}87 \mathrm{mg} / \mathrm{dl} \\
157 \mathrm{mg} / \mathrm{dl} \\
156 \mathrm{mg} / \mathrm{dl}\end{array}$ & $\begin{array}{l}\text { Up to } 95 \mathrm{mg} / \mathrm{dl} \\
<140 \mathrm{mg} / \mathrm{dl} \\
<140 \mathrm{mg} / \mathrm{dl}\end{array}$ \\
\hline Vitamin D & $46.8 \mathrm{nmol} / \mathrm{L}$ & $\begin{array}{l}\text { Deficient: }<24 \mathrm{nmol} / \mathrm{L} \\
\text { Insufficient: } 25 \text { to } 74 \mathrm{nmol} / \mathrm{L} \\
\text { Sufficient: } 75 \text { to } 250 \mathrm{nmol} / \mathrm{L} \\
\text { Potential intoxication: }>250\end{array}$ \\
\hline Calcium & $10.18 \mathrm{mg} / \mathrm{dl}$ & $8.50-10.50 \mathrm{mg} / \mathrm{dl}$ \\
\hline
\end{tabular}


baseline investigations along with calcium, vitamin D and thyroid hormone levels. Major complications after her thyroid surgery were maintenance of calcium levels but she managed it with dosage of vitamin D and calcium supplements. She regularly followed her endocrinologist. She was asked to follow up after two weeks. At 32 weeks she presented for regular check-up with normal calcium, vitamin $\mathrm{D}$ and thyroid hormone level. Fetal growth and fetal movements were satisfactory. She had deranged blood sugar levels on oral glucose tolerance test. She managed it with good diet control and blood sugar monitoring. She had good glycemic control until her delivery. Patient remained normal during whole pregnancy without having any complications of pregnancy related to thyroid surgery. She was also followed up by endocrinologist for her calcium and thyroxin levels. Her next visits were at 36 and 38 weeks. At 38 weeks her delivery was planned by elective caesarean section for good size of baby and advice of endocrinologist. Serum calcium levels were checked by the endocrinologist and pre and post-operative dosage of calcium were decided. She delivered a female baby of $3.5 \mathrm{~kg}$ on 20/2/19 with good Apgar score. Baby was shifted to nursery for monitoring of calcium levels. Patient took her adjusted dose of calcium, vitamin D and thyroxin after delivery. She was discharged after second day of delivery. She was followed up in outpatient department. She had good healthy wound and was breast feeding her baby.

\section{DISCUSSION}

Incidence of papillary thyroid carcinoma has increased in last two decades. ${ }^{4,5}$ Differentiated PTC is more common in women and its incidence increases after the age of 40 . Our patient had PTC at the age of 20 years. $^{7}$ Thyroidectomy and radioactive iodine therapy in young patients raises the concern for ovarian dysfunction. Hypothyroidism has to be adequately treated with thyroxin. Effect of radioactive iodine on ovaries is transient and it does not affect the perinatal outcome of subsequent pregnancies. ${ }^{6,7}$ Our patient was having regular menstrual periods after treatment and she conceived spontaneously. Patients with thyroid disorders may develop other metabolic and endocrine disorders. ${ }^{8,9}$ Our patient had hypocalcemia and developed gestational diabetes. Both of these were controlled by diet and oral medication. She was very compliant and had positive attitude towards her condition. She maintained her diet as advised and monitored her blood glucose regularly at home. We do not have case-controlled studies on perinatal outcome of pregnancy after treatment of PTC. Some case repots show increase caesarean section rates and low Apgar scores in fetuses of such patients. ${ }^{10}$ Reason for this is proposed to be inflammation at feto-maternal interphase, high levels of pro and antiangiogenic factors. This leads to impaired fetal per fusion. Our patient was delivered by caesarean section; baby had good Apgar score but was kept in neonatal unit for monitoring of calcium levels.

\section{CONCLUSION}

Reports of pregnancies after papillary thyroid carcinoma are rare and its management is challenging. Multidisciplinary approach and attention to their special needs can lead to satisfactory pregnancy outcome.

\section{Acknowledgements}

We are thankful to Endocrinologist (Dr. Maria Javaid), Anesthetist and Pediatrician for their support during monitoring of our patient.

\section{Conflicts of interest}

The authors had no conflict of interest to disclose.

\section{Contributors}

Initial idea and write up by Dr. Lubna Raiz Dar, proof reading of case report by Dr. Shaherzad Sohail, literature search and record collection by Dr. Afreen Farid. 


\section{REFERENCES}

1. Smith LH, Danielsen B, Allen ME, Cress R. Cancer associated with obstetric delivery: results of linkage with the California cancer registry. Am J Obstet Gynecol..2003; 189(4): 1128-35.

2. Imran SA, Rajaraman M. Management of differentiated thyroid cancer in pregnancy. J Thyroid Res. 2011; 2011:549609

3. Xhaard C, Rubino C, Cléro E, Maillard S, Ren Y, Borson-Chazot F, Sassolas G, Schvartz C, Colonna M, Lacour B, Danzon A. Menstrual and reproductive factors in the risk of differentiated thyroid carcinoma in young women in France: a population-based casecontrol study. Am J Epidemiol. 2014; 180(10): 1007-17.

4. Leenhardt L, Grosclaude P, Chérié-Challine L. Increased incidence of thyroid carcinoma in France: a true epidemic or thyroid nodule management effects? Report from the French Thyroid Cancer Committee. Thyroid. 2004; 14(12): 1056-60.

5. Sungwalee W, Vatanasapt P, Kamsa-Ard S, Suwanrungruang K, Promthet S. Reproductive risk factors for thyroid cancer: a prospective cohort study in KhonKaen, Thailand. Asian Pac J Cancer Prev. 2013; 14(9): 5153-5.
6. Sioka C, Fotopoulos A. Effects of I-131 therapy on gonads and pregnancy outcome in patients with thyroid cancer. Fertility and sterility. 2011; 95(5): 1552-9.

7. Grammatikakis I, Trakakis E, Evangelinakis N, Hintipas E, Salamalekis G, Kassanos D. Successful pregnancy after radiotherapy with 131I for differentiated thyroid cancer. A case report and review of the literature. Clin Exp Obstet Gynecol. 2010; 37(4): 328-30.

8. Guerrero-Vázquez R, Moreno Reina E, GrosHerguido N, MartínezBrocca MA, Navarro González E. Advanced thyroid carcinoma in pregnancy: case report of two pregnancies. Gynecol Endocrinol. 2015; 31(11): 852-5.

9. Eskander A, Devins GM, Freeman J, Wei AC, Rotstein L, Chauhan N, Sawka AM, Brown D, Irish J, Gilbert R, Gullane P. Waiting for thyroid surgery: a study of psychological morbidity and determinants of health associated with long wait times for thyroid surgery. Laryngoscope. 2013; 123(2): 541-7.

10. Beksaç K, Aktoz F, Örgül G, Çelik HT, ÖzgüErdinç AS, Beksaç MS. Pregnancy in papillary thyroid cancer survivors. J Turk Ger Gynecol Assoc. 2018; 19(2): 94-7. 